\title{
THE DIFFERENCE OF SOCIAL NETWORK SITES EXPLAINED WITH THE EMPLOYMENT SEEKING PROCESS
}

\author{
Tom SANDeR ${ }^{1}$, Biruta Sloka², Jurgita PauŽUolienĖ ${ }^{3}$ \\ University of Latvia (Latvia), Klaipeda University (Lithuania)
}

\begin{abstract}
This paper describes the difference between business social network sites and private social network sites under consideration of the employment seeking process. The objective of the paper is to explain the different use of social network sites for different purpose. The use of social network sites can be explained with social capital theory which has been tested with the collected data. This paper test if the social capital theory can be expanded to explain social network sites under consideration of the employment seeking process for Xing as business SNS and Facebook as private SNS. The purpose of this article: According the survey to analyze the difference of social network sites explained with the employment seeking process. The research methods: analysis of scientific literature, interpretation, quantitative research, data analysis using SPSS program. The research method has been an online survey with 271 young SNS members who are participants for the research project. The sample has a gender bias which has to be under consideration by the interpretation of the results.
\end{abstract}

KEYWORD: networks, social capital, employment seeking.

JEL CODES: L14; D24.

\section{Introduction}

The use of social networks for the employment seeking process is well researched but for SNS exist a research gap. The empirical research of SNS regarding social interaction has to be extended to get more information about SNS (Cheung et al., 2011). SNS are used from companies to identify candidates, to contact them via SNS but the use of individuals to identify information about employment opportunities or companies need deeper research (Sander, Teh, 2014). The benefit of social network sites and if people expect advantages from SNS to find employment opportunities is an interesting research question. In addition evaluates the paper the existence of differences between private and business SNS for the employment seeking process. SNS are different and individuals join networks for their benefit.

The problem of this article is based on the assumption and hypothesis. The existence of social capital in real networks is deeply researched by different authors. This paper test if the social capital theory can be

1 Tom Sander - PhD Student of University of Latvia, Department Management and Economics. Scientific interests: social network sites, social capital, recruiting processes

E-mail: tom.sander@hotmail.de

2 Biruta Sloka - professor at University of Latvia, Faculty of Economics and Management. Scientific interests: marketing research, social networks, corporate social responsibility

E-mail: Biruta.Sloka@lu.lv

3 Jurgita Paužuolienè - PhD Student of Management at Klaipėda University, Management Department. Scientific interests: organizational culture, corporate social responsibility, research on management problems in the organizations

E-mail: j.pauzuoliene@gmail.com

Tel. +37062141916 
expanded to explain social network sites under consideration of the employment seeking process for Xing as business SNS and Facebook as private SNS. Aforementioned are the variables of interest for this research are the investment of time to use social network sites per week (Wang 2014), duration of membership in social network sites and the number of contacts lead to the assumption:

- Duration of membership, number of contacts and use in minutes per week of social network sites influence the employment seeking process of individuals at SNS.

- Social network sites have different purpose, sense and objectives which influence the use of SNS.

The assumptions are based on a literature review and give an indication that the use of social network sites influences the social capital of an individual. Social capital is an important part to explain causal mechanism in SNS. The investment in social capital is the time, effort and maintenance of ties to have access to resources and information. That is the assumption to test with the collected data.

The object of the article is the difference between private and business social network sites.

The purpose of this article: According the survey to analyze the difference of social network sites explained with the employment seeking process.

The research methods: analysis of scientific literature, interpretation, quantitative research, data analysis using SPSS program.

\section{Review of the literature}

Social network sites (SNS) are an important factor for the society and change the society. The influence of SNS on the society is increasing (Lai, Yang 2014)"type" : "article-journal" \}, "uris" : [ "http://www. mendeley.com/documents/?uuid=fffe0b50-dfc2-4fe7-9620-ac9a85a2955c"] \} ], "mendeley" : "formattedCitation" : "(Lai \& Yang 2014. The SNS provide new opportunities for individuals to exchange information and to support each other. This paper concentrates on the employment seeking process of individuals in Germany. The SNS which has been used for this research has been Facebook and Xing. Facebook is an ambassador for private SNS which is socially organized (Ellison et al., 2007; Caers et al., 2013). Private SNS have the purpose to organize the private life of individuals e.g. to find friends or to exchange picture. The benefit of the private SNS is to forward information about private life fast and easily to a large defined group of friends. The private SNS present the private life to a large audience, to maintain private relationships and the main function is the social interaction (Lai, Yang, 2014)"type" : "article-journal" \}, "uris" : [ "http://www. mendeley.com/documents/?uuid=fffe0b50-dfc2-4fe7-9620-ac9a85a2955c"] \} ], "mendeley" : \{ "formattedCitation" : "(Lai \& Yang 2014. Business social network sites profiles include professional information and information about skills and educational level of individuals. Business SNS member have the opportunity to present their human capital and social capital to a large audience, business social network sites provide the opportunity to identify individuals with special skills, knowledge or decision maker. The business SNS are professional networks for business issues (Vock et al. 2013). The business SNS provides information and access to information which could be important for the business world e.g. contact details of purchase manager to sell products (Caers, Castelyns, 2010). The aim of business SNS is to create a beneficial network for business issues to give individual the access to beneficial information, contacts and resources. None member of business SNS do not have this advantage and that is the benefit for business SNS.

Social network sites are online tools to exchange information and to create a profile to present themselves to a large audience. Further is it possible to use social network sites to communicate with each other. Xing and Facebook are popular SNS in Germany and well known by individuals in Germany. Former research included Google+ and Linkedin but those pages are not well known by German individuals. In former research has lead this issue to some biases. That is the reason to concentrate on Xing and Facebook as an ambassador for business network sites and private network sites. The SNS have different purpose which influences the attractiveness of the SNS for the individual. The SNS are exclusive for the members and the benefit is that none members are excluded. Individuals joining network sites because they have a benefit. 
Social capital explains the behaviour of individuals in social networks (Sabatini, Sarracino, 2014; Valenzuela et al., 2009). There are many definitions on social capital in the literature. Some authors explain social capital with the structure of the networks or the position of individuals in the network (Granovetter, 2005; Burt, 2000)my summary points are three: (1. Other authors explain social capital with factors like trust, exchange, obligations or reciprocity. This paper concentrates on the use of SNS to support each other for the employment seeking process (Lin, 2001). The research evaluates if both kind of networks are used in the same way to identify employment opportunities, how SNS support the employment seeking process. Further is of interest to identify variables to explain the use of SNS and to identify correlations between variables to explain reasons to use SNS for the employment seeking process. The measure of social capital in this paper concentrates on the investment in the network. The investment in the network is the effort of the individual to maintain ties and to exchange information or resources. This paper measures the efforts in time. One variable which is described below deeply is the weekly use of SNSs per weeks in minutes. Other relevant information is the duration of membership in SNSs in years. The duration of the membership in SNS is an indicator for the trust which is present in the SNS. People who have experience with the SNS know what they can expect and they would not stay with the SNS if they could not trust the tool (Van Der Gaag, Snijders, 2005; Nahapiet, Ghoshal, 1998). One more variable is the number of ties of an individual to explain social capital. People with many ties have many opportunities to get access to resources and information (Mouw, 2003; Feuls et al., 2014). This number of ties is an indicator for prestige because only people who have valuable opportunities would have many ties. It is important who individuals know to be successful and to reach their objective (Ibarra, Hunter, 2007)feedback, insight, and resources--is an essential activity for an ambitious manager. Indeed, it's a requirement even for those focused simply on doing their current jobs well. For some, this is a distasteful reality. Working through networks, they believe,means relying on \"who you knowl" rather than \"what you knowl"--a hypocritical, possibly unethical, way to get things done. But even people who understand that networking is a legitimate and necessary part of their jobs can be discouraged by the payoff--because they are doing it in too limited a fashion. On the basis of a close study of 30 emerging leaders, the authors outline three distinct forms of networking. Operational networking is geared toward doing one's assigned tasks more effectively. It involves cultivating stronger relationships with colleagues whose membership in the network is clear; their roles define them as stakeholders. Personal networking engages kindred spirits from outside an organization in an individual's efforts to learn and find opportunities for personal advancement. Strategic networking puts the tools of networking in the service of business goals. At this level, a manager creates the kind of network that will help uncover and capitalize on new opportunities for the company. The ability to move to this level of networking turns out to be a key test of leadership. Companies often recognize that networks are valuable, andthey create explicit programs to support them. But typically these programs facilitate only operational networking. Likewise, industry associations provide formal contexts for personal networking. The unfortunate effect is to give managers the impression that they know how to network and are doing so sufficiently. A sidebar notes the implication for companies' leadership development initiatives: that teaching strategic networking skills will serve their aspiring leaders and their business goals well.", "author" : [ \{ “dropping-particle" : "”, "family": "Ibarra”, "given" : "Herman", "nondropping-particle" : "”, "parse-names" : false, "suffix" : "” \}, \{dropping-particle" : “", "family" : "Hunter", "given" : "Mark", "non-dropping-particle" : “", "parse-names" : false, "suffix" : “" \} ], "container-title" : "Harvard business review", "id" : "ITEM-1", "issue" : "1", "issued" : \{ "date-parts" : [ [ "2007", "1"] ] \}, "page" : "40-7, 124", "title" : "How leaders create and use networks.", "type" : "article-journal", "volume" : "85" \}, "uris" : [ "http://www.mendeley.com/documents/?uuid=4b6871d0-036d-4f66-9ef7-08a526c90317" ] \} ], "mendeley" : \{ "formattedCitation" : "(Ibarra \& Hunter 2007. That means the third variable to identify a relationship between SNS and social capital is the number of contacts. These three indicators are the basis of explanation of social capital in SNSs. Without an investment of individuals would be the value of SNSs membership not possible. A social network site needs their members with their resources and information to be successful. 


\section{Methodology of the research}

In this survey was used the quantitative research, an online questionnaire. The online survey has been done in April 2015 with a student project and a number of questions about the topic recruitment and employer branding. Online surveys are very useful for research of social network sites because the user of social network sites have to use the internet. The access to the internet is given and the user of social network sites are trained with online tools (Wright, 2005; Evans, Mathur, 2005). All questions have had a six point Likert scale from one very supportive to six completely unsupportive. The six point scale has been chosen as in Germany it is used six point evaluation system in schools, where 1 is the highest level and 6 is the lowest level. The survey has been online as the questions concentrates on SNS and individuals without internet access are not able to take part in SNS but the respondents were selected using systematic sample and approached via internet.

The results represented in the paper are obtained by use of SPSS (Statistical Package for the Social Sciences) program to analyze the data and used www.soscisurvey.de (retrieved 10.06.2015) to collect the data. For statistical analysis of data have been used frequency, indicators of central tendency or location: arithmetic mean (the average of the evaluations), median (the middle value in the list of range devaluations) and indicator of variability - standard deviation. Standard deviation shows how much variation or dispersion exists from the average (mean), or expected value. A low standard deviation indicates that the data points tend to be very close to the mean; high standard deviation indicates that the data points are spread out over a large range of values. Also processing the data was used the Pearson correlation. These tests provide an answer about the use of SNS and provide the opportunity to compare private and business SNS. The data collected in accordance with research ethics.

In total 230 participants $(n=230)$ filled out the complete questionnaire. The gender distribution is $35.4 \%$ men and $64.6 \%$ woman. The gender question has been answered by 229 participants. The most participants are under 36 years old. That distribution of gender proportion as well as age group is typical for this topic because young people use more often the internet and SNS(Wang, 2014). Further has been the data collected with the support of the students who distributed the questionnaire to the participants of the survey.

The education level is differentiated in $50.87 \%$ participants have had an practical training or finished an apprenticeship. The question about an educational degree is answered by $\mathrm{n}=230$. The educational level is with $25.22 \%$ a school degree. An university degree have $22.61 \%$ of the participants and a doctoral degree or higher degree have $1.30 \%$. This result is explainable with the age distribution.

\section{Analysis of the difference between private and business SNS}

The use of business SNS and private SNS is different. The table below describes the social capital with the above mentioned variables use in minutes per week, membership in years and number of contacts.

Table 1. Mean, median, standard deviation (SD) and $\mathrm{n}$ for indicators to explain SC in SNS

\begin{tabular}{|l|l|l|l|l|}
\hline The differences between private and business SNS & N & Mean & Median & SD \\
\hline Use in minutes per week of private SNS & 178 & 3.74 & 4 & 1.383 \\
\hline Use in minutes per week of business SNS & 78 & 2.86 & 2 & 1.346 \\
\hline Number of contacts at private SNS & 168 & 287.87 & 200 & 256.165 \\
\hline Number of contacts at business SNS & 69 & 107.62 & 25 & 273.524 \\
\hline Membership in years at private SNS & 174 & 6.14 & 5 & 3.966 \\
\hline Membership in years at business SNS & 72 & 2.89 & 2 & 2.790 \\
\hline
\end{tabular}

Source: Data conducted by Tom Sander, 2015

Table 1 provides information about the use of private and business SNS. The data explains clearly that there are differences between the networks which corresponds with results of other scientific publications 
(Vergeer, 2014; Twitter has become a major force in modern societies and also in the production of news by journalists. How journalists use Twitter is studied extensively, particularly on a small scale (i.e., qualitative research, specific events, mostly descriptive Kietzmann et. al., 2011). Already the number of participants who are member of private SNS is significant higher than the member of business SNS. The arithmetic mean value of contacts at private SNS is 2.67 times more than at business social network sites. The arithmetic mean of the duration of membership is 2.12 higher at private SNS than at business SNS. The arithmetic mean of use of SNS in minutes per week describes that individuals use 1.30 times more often private social network sites than business social network sites in minutes per week. Participants are only using some minutes per week to use business SNS. The median values explain more deep the ratio between the both different SNSs. Private and business network sites are different and differently used. That can be explained with the popularity of private SNS for young people and more people use private SNS (Statistisches Bundesamt, 2014). This can explain the differences.

The paper describes the differences of SNS under consideration of the employment seeking process. The survey asked the participants if SNSs are supportive or completely unsupportive for the employment seeking process. The scale is a six point Likert scale from one for supportive to six for completely unsupportive.

The evaluation of private SNS explain that individuals are not percipience private SNS as valuable for the employment seeking process. The participants choice the $3^{\text {rd }}, 4^{\text {th }}$ or $6^{\text {th }}$ point on the scale with $71.1 \%$. That is a clear tendency not to use private SNS for the employment seeking process.

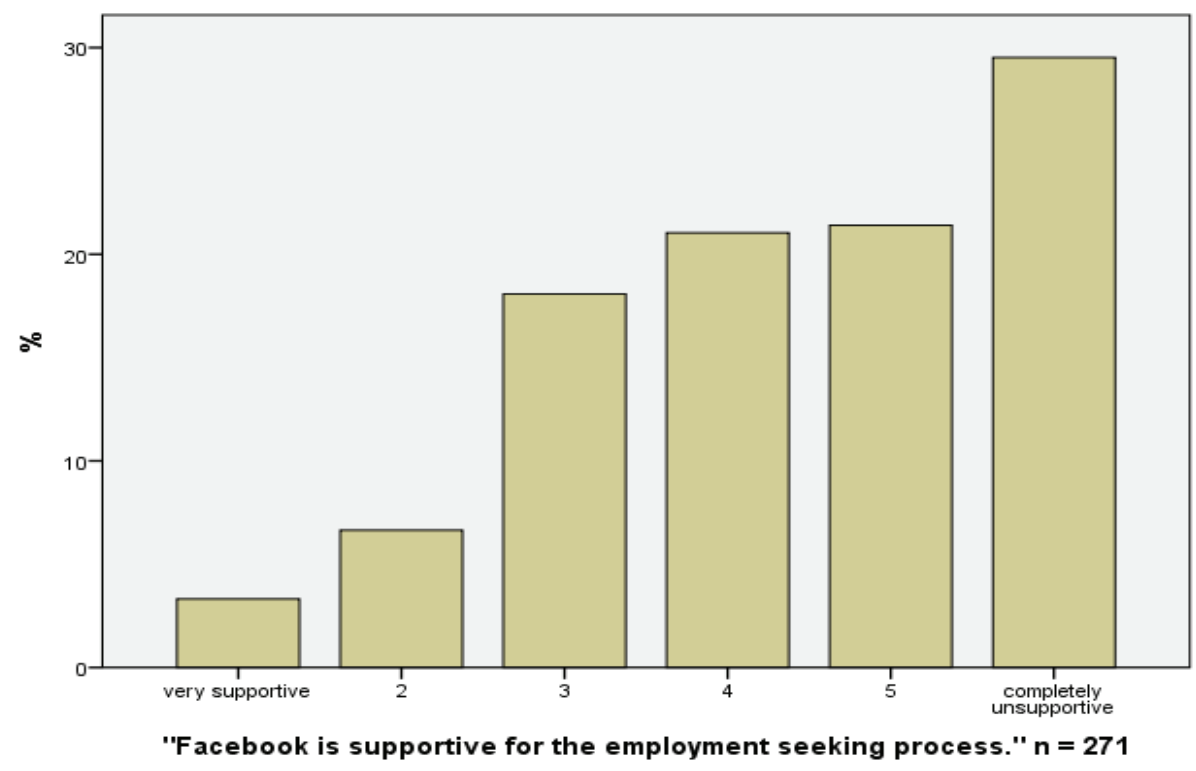

Figure 1. Facebook is supportive for the employment seeking process $(n=271)$

Source: Data conducted by Tom Sander, 2015

Only $1.3 \%$ evaluate private SNS as very supportive to identify employment opportunities (figure 1). That means the individuals do not use private SNS to exchange information about employment opportunities and individuals do not anticipate a benefit to use private SNS.

The statement about business SNS support for the employment seeking process provides a contraire distribution to private SNS. The individual's response that business SNS are very supportive for the employment seeking process and the tendency is strong to supportive. More than $76.1 \%$ choice on the scale one, two or three. One explanation can be the experience of the participants with the different kind of SNS. The aforementioned data explain that less participants have experience with business SNS. The investment (time of use, duration of membership) at business SNS is distinct below private SNS (Statistisches Bundesamt, 
2014). The similar situation has been with number of contacts at private and business SNS. These are explanations to explain the use of SNSs for the employment seeking process and can explain the differences between the two kinds of networks.

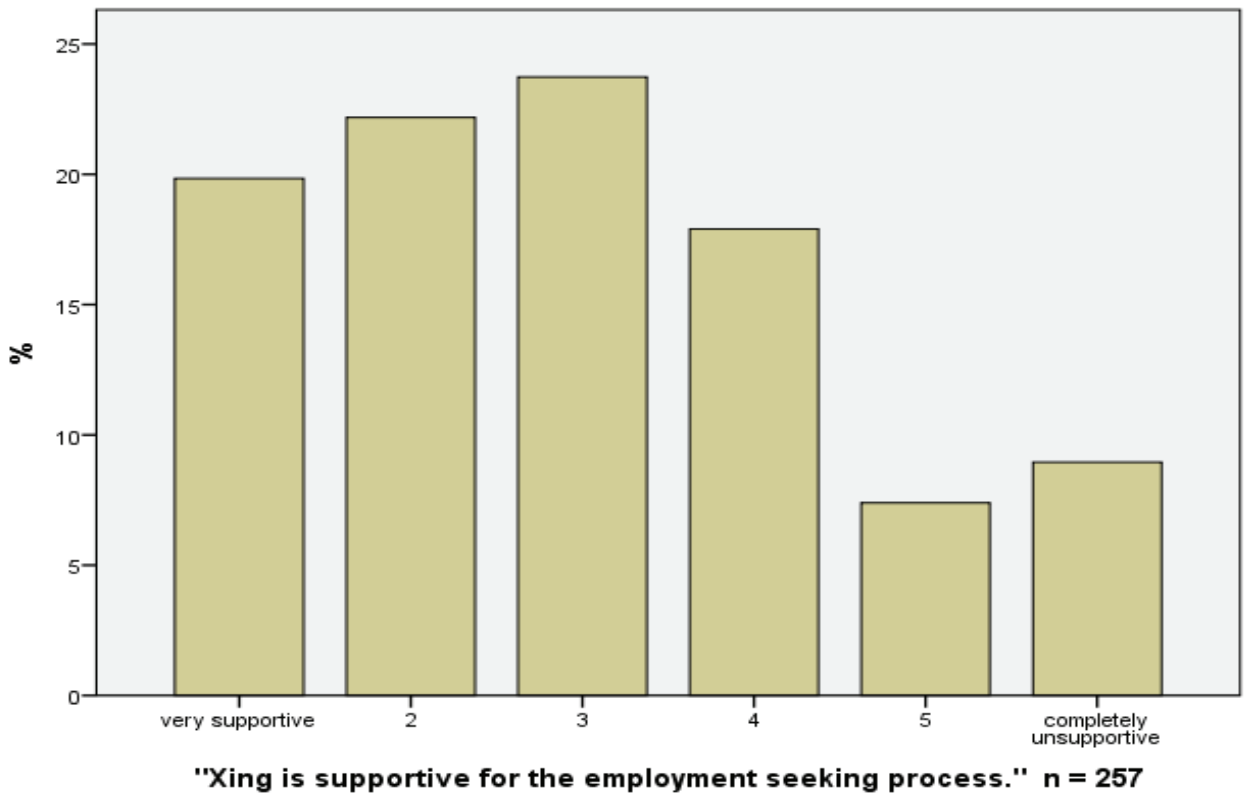

Figure 2. Xing is supportive for the employment seeking process $(n=257)$

Source: Data conducted by Tom Sander, 2015

The next step is to provide more explanations about the use of business and private SNS test the paper the correlation between the supportiveness and the variables membership in years of business SNS, number of contacts and use of business SNS in minutes per week (Lai, Yang, 2014)"type" : "article-journal" \}, "uris" : [ "http://www.mendeley.com/documents/?uuid=fffe0b50-dfc2-4fe7-9620-ac9a85a2955c"] \} ], "mendeley" : \{ "formattedCitation" : "Lai \& Yang 2014. The results of the correlation, significance and $\mathrm{n}$ are provided in the table 2 .

Table 2. Pearson coefficients of correlations of variables to evaluate the relationship among variables the involvement in business SNS of Xing member and Xing is supportive for the employment seeking process

\begin{tabular}{|l|l|l|}
\hline \multicolumn{1}{|c|}{ Selections } & \multicolumn{2}{|c|}{ Xing is supportive for the employment seeking process } \\
\hline Member of Business SNS since & Correlation & 0.068 \\
$\ldots$... years & Significant (2 sides) & 0.585 \\
& $\mathrm{n}$ & 66 \\
\hline Number of contacts in Business & Correlation & -0.238 \\
SNS & Significant (2 sides) & 0.058 \\
& $\mathrm{n}$ & 64 \\
\hline Use of Business SNS in minutes & Correlation & -0.1 \\
per week & Significant (2 sides) & 0.407 \\
& $\mathrm{n}$ & 71 \\
\hline
\end{tabular}

Source: Data conducted by Tom Sander, 2015

The results gives the indication that the use of business SNS do not have any correlation with the experience of supportiveness of business SNS for the employment seeking process. The number of contacts in Business SNS and use of Business SNS in minutes per week have a negative weak correlation. 
The next step has been to test the correlation of private SNS and duration of membership, number of contacts and weekly use of private SNS. The results of the correlation, significance and $\mathrm{n}$ are provided in the table 3 .

Table 3. Pearson coefficients of correlations of variables to evaluate the relationship among variables the involvement in private SNS of Facebook member and Facebook is supportive for the employment seeking process

\begin{tabular}{|l|l|l|}
\hline \multicolumn{1}{|c|}{ Selections } & Facebook is supportive for the employment seeking process \\
\hline $\begin{array}{l}\text { Member of private SNS } \\
\text { since .... years }\end{array}$ & Correlation & -0.006 \\
& Significant (2 sides) & 0.939 \\
& $\mathrm{~N}$ & 168 \\
\hline Number of contacts in & Correlation & 0.093 \\
private SNS & Significant (2 sides) & 0.236 \\
& $\mathrm{~N}$ & 164 \\
\hline $\begin{array}{l}\text { Use of private SNS in } \\
\text { minutes per week }\end{array}$ & Correlation & -0.037 \\
& Significant (2 sides) & 0.64 \\
& $\mathrm{~N}$ & 160 \\
\hline
\end{tabular}

Source: Data conducted by Tom Sander, 2015

The correlation is weak and none significant with significance level 0.05 or 0.01 . The duration of membership is negative and very weak. The use of private SNS in minutes per weak is negative and weak. The only positive result for the correlation is the number of contacts but the result is with 0.093 very weak.

Results show that the duration of membership in SNS in years gives the indication that an individual has experience and created trust in the SNS and invested many time in SNS. This variable does not correlate with the use of SNSs to be supportive for the employment seeking. The variable - number of contacts is an indication that a member has many opportunities to get access to information and resources. This person knows many people who could support for the employment seeking process. The number of contacts does not have a correlation with the employment seeking of individuals which has to be mentionable. The last variable use of SNS per week in minutes describes the investment in SNSs. Time is money and the regularly use of SNS is an indication that the person trust the SNS because if the person would not trust than the amount of time to use SNS would be less. They have a benefit with SNS and that is the reason to use SNS more time than other member does that.

\section{Conclusions}

Explaining the differences using of business SNS and private SNS, results indicates that individuals prefer business SNS for the employment seeking process. The reason for the difference is the aim and use of business SNS and private SNS. Individuals do not think that private social network sites are supportive for the employment seeking process. That means they do not use or receive any useful information for the employment seeking process. The frequency is a clear result and evidence that SNS have different purpose, tasks and usefulness for individuals. That means they are using their membership in networks for different aims to get access to different information. That is a part of social capital, individuals are member to get access to needed or desirable resources and information.

The paper tests the correlation of membership attributes and use of SNS for the employment seeking process. All three variables explain the expectation to get access to needed resources and information or they can provide resources and information to other individuals to create a benefit. That is the social capital and social investment of individuals which have provides a benefit to individuals but the use of SNSs as a supportive tool to identify employment opportunities or to exchange information about employment opportunities is 
not possible for example. The relevance of private SNS for the employment SNS is not explainable with the variables and private SNS is not used for the employment seeking process. The relevance of business SNS for the employment seeking process is high and individuals use business SNS for the employment seeking process but the behaviour cannot be explained with the tested variables.

\section{Further research and Limitations}

The research needs deeper tests and a more representative sample. The sample has the weakness that the gender distribution is biased. The participants are mainly young people below 36 years. The results cannot be generalized on SNS because the concentration for this survey has been on Xing and Facebook. Further research should have more different SNSs under consideration or should not ask for specific SNSs to give a general answer on the use of private or business SNS for the employment seeking process. The weakness of the correlations has to be under consideration and the result has to be that the influence of the used variables is low. Further research has to identify new variables to explain more and deeper the use of SNSs for the employment seeking process. In addition is the result not significant which make it difficult to use the results.

The next step has to be a research with a new sample to confirm or disconfirm the results of this research and to explain the use of SNS deeper. The variables should be used for a regression analysis with the new sample to five a deeper insight to evaluate the differences between SNS and the use of employment seeking process of SNS.

\section{References}

Burt, R. S. (2000). The network structure of social capital. In: R. I. Sutton, B. M. Staw (eds.). Research in Organizational Behavior, Vol. 22(May), p. 345-423.

Caers, R. et al. (2013). Facebook: A literature review. New Media \& Society, Vol. 15(6), p. 982-1002. Available at: http://nms.sagepub.com/cgi/doi/10.1177/1461444813488061 [accessed December 11, 2013].

Caers, R., Castelyns, V. (2010). LinkedIn and Facebook in Belgium: The Influences and Biases of Social Network Sites in Recruitment and Selection Procedures. Social Science Computer Review, Vol. 29(4), p. 437-448. Available at: http://ssc.sagepub.com/cgi/doi/10.1177/0894439310386567 [accessed July 19, 2012].

Cheung, C. M. K., Chiu, P. Y., Lee, M. K. O. (2011). Online social networks: Why do students use facebook? Computers in Human Behavior, Vol. 27(4), p.1337-1343.

Ellison, N. B., Steinfield, C., Lampe, C. (2007). The benefits of facebook "friends": Social capital and college students' use of online social network sites. Journal of computer mediated communication, Vol. 12, p. 1143-1168.

Evans, J. R., Mathur, A. (2005). The value of online surveys. Internet Research, Vol. 15(2), p. 195-219. Available at: http://www.emeraldinsight.com/10.1108/10662240510590360 [accessed July 11, 2014].

Feuls, M., Fieseler, C., Suphan, A. (2014). A social net? Internet and social media use during unemployment. Work, Employment \& Society, p. 1-20. Available at: http://wes.sagepub.com/cgi/doi/10.1177/0950017013519846 [accessed June 11, 2014].

Van Der Gaag, M., Snijders, T. a. B. (2005). The Resource Generator: social capital quantification with concrete items. Social Networks, Vol. 27(1), p. 1-29. Available at: http://linkinghub.elsevier.com/retrieve/pii/S0378873304000607 [accessed March 9, 2012].

Granovetter, M. (2005). The impact of social structure on economic outcomes. The Journal of Economic Perspectives, Vol. 19(1), p. 33-50. Available at: http://www.jstor.org/stable/10.2307/4134991 [accessed June 9, 2012].

Ibarra, H., Hunter, M. (2007). How leaders create and use networks. Harvard business review, Vol. 85(1), p. 40-7, 124.

Kietzmann, J. H. et al. (2011). Social media? Get serious! Understanding the functional building blocks of social media. Business Horizons, Vol. 54(3), p. 241-251. Available at: http://linkinghub.elsevier.com/retrieve/pii/ S0007681311000061 [accessed March 1, 2012].

Lai, C. Y., Yang, H. L. (2014). Determinants and consequences of Facebook feature use. New Media \& Society, p. 1-21.

Lin, N. (2001). Building a network theory of social capital. In: N. Lin, K. Cook, R. Burt (eds.). Social capital theory and research. New Jersey, p. 3-30.

Mouw, T. (2003). Social capital and finding a job: Do contacts matter? American sociological review, Vol. 68, p. 868898. Available at: http://www.jstor.org/stable/10.2307/1519749 [accessed September 29, 2013]. 
Nahapiet, J., Ghoshal, S. (1998). Social Capital, Intellectual Capital, and the Organizational Advantage. The Academy of Management Review, Vol. 23(2), p. 242.

Sabatini, F., Sarracino, F. (2014). Will Facebook save or destroy social capital? An empirical investigation into the effect of online interactions on trust and networks. Köln.

Sander, T., Teh, P. L. (2014). A Method to Identify Research Gaps in the Literature for the Social Capital Theory for Social Network Sites under Consideration of the Employment Seeking Process. RISEBA Conference. Riga.

Statistisches, Bundesamt. (2014). Wirtschaftsrechnungen - Private Haushalte in der Informationsgesellschaft - Nutzung von Informations - und Kommunikationstechnologien. Wiesbaden.

Valenzuela, S., Park, N., Kee, K. F. (2009). Is There Social Capital in a Social Network Site?: Facebook Use and College Students' Life Satisfaction, Trust, and Participation. Journal of Computer-Mediated Communication, Vol. 14(4), p. 875-901. Available at: http://doi.wiley.com/10.1111/j.1083-6101.2009.01474.x [accessed October 26, 2012].

Vergeer, M. (2014). Peers and sources as social capital in the production of news: Online social networks as communities of journalists. Social Science Computer Review, Vol. 33(3), p. 277-297.

Vock, M. et al. (2013). Understanding Willingness to Pay for Social Network Sites. Journal of Service Research, Vol. 16(January), p. 1-15.

Wang, X. (2014). How Do People Participate in Social Network Sites After Crises? A Self-Determination Perspective. Social Science Computer Review, Vol. 32(5), p. 662-677.

Wright, K. B. (2005). Researching Internet-Based Populations: Advantages and Disadvantages of Online Survey Research, Online Questionnaire Authoring Software Packages, and Web Survey Services. Journal of Computer-Mediated Communication, Vol. 10(3).

\section{SOCIALINIU TINKLŲ SKIRTUMAI AIŠKINANT DARBO PAIEŠKOS PROCESA}

Tom Sander, Biruta Sloka, Jurgita Paužuolienė

Latvijos universitetas (Latvija), Klaipėdos universitetas (Lietuva)

\section{Santrauka}

Straipsnyje aprašomas skirtumas tarp verslo socialinių tinklų ir privačių socialinių tinklų svetainių darbo paieškos procese. Šio straipsnio tikslas - paaiškinti pagrindinius skirtumus darbo paieškos procese naudojantis socialinių tinklų svetainėmis. Pabrěžiama, kad socialinių tinklų svetainių naudojimą galima paaiškinti remiantis socialinio kapitalo teorija, kuri patikrinta surinktais tyrimo duomenimis. Straipsnyje atskleidžiama, kaip socialinio kapitalo teorija gali būti išplètota norint paaiškinti socialinių tinklų svetainių skirtumus darbo paieškos procese, analizuojant Xing, kaip verslo socialinio tinklo svetainę, ir Facebook, kaip privačią socialinio tinklo svetainę. Šio tyrimo kintamieji: laiko investicijos naudojantis socialiniais tinklais per savaitę, narystės trukme socialiniuose tinkluose ir kontaktu skaičius. Remiantis šiais kintamaisiais keliamos hipotezès: narystės trukmè, kontaktų skaičius ir naudojimosi socialinių tinklų svetainėmis laikas turi įtakos darbo ieškantiems individams; socialinių tinklų svetainių paskirtis ir tikslai - skirtingi. Darbo objektas - privačių ir verslo socialinių tinklų svetainių skirtumai. Darbo tikslas: remiantis apklausos rezultatais, išanalizuoti socialinių tinklų svetainių skirtumus atsižvelgiant ị darbo paieškos procesą. Taikyti metodai: literatūros analizè, interpretacija, kiekybinių tyrimo duomenų analizè apdorojant duomenis SPSS programa. Straipsnyje renkant kiekybinius tyrimo duomenis pasinaudota internetine apklausa, kurioje dalyvavo 271 jaunų socialinių tinklų svetainių narys.

Atlikus tyrimą išsiaiškinta, kad visi trys kintamieji (laiko investicijos naudojantis socialiniais tinklais per savaitę, narystės trukmė socialiniuose tinkluose ir kontaktų skaičius) paaiškina lūkesčius gauti prieigą prie reikalingų išteklių ir informacijos, arba tai gali suteikti išteklių ir informacijos kitiems asmenims siekiant naudos. Tai yra socialinis kapitalas ir individų socialinė investicija, kuri naudinga asmenims, tačiau naudotis 
socialinių tinklų svetainėmis kaip pagalbine priemone, siekiant nustatyti galimybes įsidarbinti arba keistis informacija apie įsidarbinimo galimybes, neįmanoma. Išsiaiškinta, kad privačių socialinių tinklų nenaudojimas darbo paieškos procese yra žemas. Tuo tarpu verslo socialinių tinklų naudojimas darbo paieškos procese yra aukštas, tačiau tirtų asmenų elgesio negalimai paaiškinti šiais tirtais kintamaisiais.

PAGRINDINIAI ŽODŽIAI: tinklai, socialinis kapitalas, darbo paieška.

JEL KLASIFIKACIJA: L14; D24. 